\title{
Long-term spatio-temporal expansion of the native-invasive Retama monosperma on coastal dunes: Importance of land-use and natural dispersal vectors
}

\author{
Sara Muñoz-Vallés*, Juan B. Gallego-Fernández, Claudia Dellafiore, Jesús Cambrollé \\ Departamento de Biología Vegetal y Ecología, Universidad de Sevilla, Ap.1095, 41080 Seville, Spain
}

\section{A R T I C L E I N F O}

\section{Article history:}

Received 19 January 2012

Received in revised form 3 March 2013

Accepted 9 March 2013

Available online 1 May 2013

\section{Keywords:}

Dune stabilization

Land-cover change

Seed dispersal

Livestock

Wild rabbit

SW Spain

\begin{abstract}
A B S T R A C T
Expansion of invasive species inducing sands stabilization is becoming an important ecological problem in coastal dunes in some parts of the world. Retama monosperma, an endemic to coasts of SE Spain and NE of Morocco, late-colonizing shrub occurring in sandy coastal areas, was planted along the coast of SW Spain during the 20th century to stabilize dunes. In recent decades, the species has spread rapidly, becoming invasive, and sometimes incurring notable changes in its environment and plant community. The expansion patterns of $R$. monosperma from 1956 to 2001 were described and quantified at the landscape scale within a protected dune system, using GIS. The differential effects on expansion patterns of the main factor controlling the population spread, grazing by domestic livestock and the abundance of wild rabbits, were analyzed comparatively. $R$. monosperma displays an exponential, invasive-type expansion trend, presenting a mean annual coverage increase of $15 \%$ and a mean lateral spread rate of $65.5 \mathrm{~m} \mathrm{yr}^{-1}$ from the original population nucleus to the Western and Eastern ends of the study area. The dispersal activity primarily of rabbits and the absence of competing woody species contribute to this rapid expansion. The highest local increases in plant coverage could be related to increased rabbit abundance and to the improved germination rates of seeds which have passed through the rabbit gut. In contrast, areas highly grazed by livestock present the lowest increases, and an open-type plant community is maintained there for a longer time.
\end{abstract}

(c) 2013 Elsevier GmbH. All rights reserved.

\section{Introduction}

The process of coastal dune stabilization consists of the progressive reduction of sand movement, closely related to an increase in vegetation coverage, and following a positive feedback mechanism (Yizhaq et al., 2007). The process involves significant changes in dune geomorphology and other environmental characteristics, such as lower incidence of wind and salt spray and increases in soil organic matter and nutrients (El-Bana et al., 2002; Muñoz Vallés et al., 2011) as well as in the type of flora and fauna supported by the dunes (Lichter, 1998; Levin and Ben-Dor, 2004; Plassmann et al., 2010). In different parts of the world, dune stabilization is having a negative impact on the richness and diversity of dune plant and animal species of high conservation value, and is becoming an important environmental problem (Avis, 1995; Alvarez and Cushman, 2002; Conser and Connor, 2009; Isermann et al., 2007; Isermann, 2008; Kutiel et al., 2004a; Marchante et al., 2008; Wiedemann and Pickart, 1996). At present, fixation and

\footnotetext{
* Corresponding author. Tel.: +34 954557 165; fax: +34 954626308.

E-mail addresses: saramval@us.es (S. Muñoz-Vallés), galfer@us.es (J.B. GallegoFernández), cdelaflor7@hotmail.com (C. Dellafiore), cambrolle@us.es (J. Cambrollé).
}

stabilization of coastal dunes are identified by several authors as one of the main threats to these ecosystems (Isermann et al., 2007; Jørgensen and Kollmann, 2008; Kutiel et al., 2004a).

The recent increase in stability of coastal dunes has been caused, in certain cases, by factors such as global or local climatic change (Panario and Piñeiro, 1997; Tsoar, 2005; Tsoar et al., 2009) and changes in agricultural and livestock uses (Isermann et al., 2007; Levin and Ben-Dor, 2004; Plassmann et al., 2010); or as a result of a decrease in herbivory by domestic livestock or wild grazers such as rabbits (Hodgkin, 1984; Levin and Ben-Dor, 2004; Ranwell, 1960, 1972; Thomas, 1963). In many cases, however, dune stabilization has been directly anthropogenic and is the product of attempts to prevent dune erosion and to stabilize blowing transgressive sand sheets (Pye, 1983). Since the late 18th century, various countries have implemented dune fixation and stabilization techniques that include planting rapid-growth herbaceous and/or woody species tolerant to environmentally stressful dune conditions, such as e.g. Ammophila arenaria, Hippophae rhamnoides, Rosa rugosa, several species of the genus Carpobrotus, Acacia, Eucalyptus, Pinus and Retama, among others, with no regard to their exotic character in terms of the ecosystem in which they were planted (Avis, 1989; Buell et al., 1995; Isermann, 2008; Kith-y-Tassara, 1946; Kollmann et al., 2009; Kutiel et al., 2004a,b; Wiedemann and Pickart, 1996). 
Over time, many of these species have spread beyond their initial plantation areas, further stabilizing the surrounding dune systems, and sometimes exhibiting invasive behaviour and causing serious problems for the conservation of the coastal dune ecosystems (Avis, 1995; Conser and Connor, 2009; Marchante et al., 2008; Zunzunegui et al., 2012).

Coastal dune areas are susceptible to plant invasion because of the open nature of the plant communities and existence of micro-sites suitable for species establishment, as well as typically low levels of plant-plant competition (Jørgensen and Kollmann, 2008). In recent years, the importance of the expansion of exotic species in coastal dunes and their potential to induce changes in the structure and functioning of resident communities, have been recognized (Sakai et al., 2001; Valéry et al., 2009). A limited number of studies deal with the invasive expansion of native species within their natural area of distribution (Peters et al., 2006; Van Auken, 2000). Such studies are particularly scarce in the case of coastal dunes (Isermann et al., 2007; Isermann, 2008; Nielsen et al., 2011), where the rapid expansion and increase in coverage of some species, particularly shrubs, significantly contributes to the dune stabilization process, altering the functioning of the entire ecosystem. An analysis of historical invasions, spread rates and patterns, conducted at the landscape scale, can be linked to proximate causes and can contribute to an understanding of how changes in structure and functioning of dune ecosystems occur (Valéry et al., 2009; Vilà and Ibáñez, 2011). Such analyses can also be used to model future spread (Kollmann et al., 2009), as well as help to determine the effectiveness of different management practices (Ansley et al., 2001).

Along the coast of SW Spain, Retama monosperma (L.) Boiss. (Talavera, 1999), a N-fixing leguminous native shrub, was sown in coastal dunes during the 20th century, either alone or together with other species like Pinus pinea and Ammophila arenaria, in order to stabilize the dunes (Kith-y-Tassara, 1946). In most of the locations where it was planted without other species, $R$. monosperma has displayed invasive behaviour and has rapidly expanded beyond the plantation areas (Valdés et al., 2007). It has caused 'retamar' formations in high densities that have led to sand stabilization in open, semi-stabilized dunes and induced substantial changes in dune soil and plant community, as well as at the landscape level (Muñoz Vallés et al., 2011; Zunzunegui et al., 2012). In addition, the species is presently considered to be a non-native invasive plant in other countries around the world such as USA (California: Cal-IPC, 2006; Randall, 1997; Rejmanek and Randall, 1994) and Australia (Randall, 2007).

The expansion of a plant species is dependent on its life history characteristics, including the production and dispersal of propagules, the characteristics of the resident ecosystem and the prevailing environmental conditions (Peters et al., 2006). In this regard, conservation and management approaches, as well as disturbances, can affect population trends in vegetation.

In coastal dunes, wild rabbits, hares and livestock are the main potential dispersal agents of $R$. monosperma (Dellafiore et al., 2006). On the other hand, the traditional use of dunes as livestock grazing areas, or the presence of wild grazers, have often controlled the excessive growth of plant coverage and encroachment, becoming an important factor in the maintenance of low vegetation coverage in semi-stabilized dunes and their characteristic open-type communities (Kooijman and Van der Meulen, 1996; Levin and Ben-Dor, 2004; Manzano and Návar, 2000; Zhao et al., 2005). Land use type and policies for nature conservation and management could therefore play an important role in controlling trends of $R$. monosperma expansion in the coastal dunes where the species grows.

This study presents a detailed reconstruction of the historical expansion of $R$. monosperma on a dune landscape by using aerial photography and GIS analysis. Specific objectives were: (1) to model the expansion of $R$. monosperma over the dune landscape, (2) to find out variations in expansion rates and spatio-temporal trends, and (3) to test how the presence of livestock and abundance of wild rabbits, conditioned by the policies of natural areas conservation, could act to influence the invasion process.

\section{Materials and methods}

\section{Study area}

The study was conducted on the El Rompido spit, a semiisolated and protected dune system located in the Piedras river estuary, in the central coastal region of the Gulf of Cadiz, SW Spain $\left(37^{\circ} 12^{\prime} \mathrm{N}, 7^{\circ} 07^{\prime} \mathrm{W}\right)$, and included in the natural range of $R$. monosperma (Fig. 1). The spit stretches eastwards for approximately $12 \mathrm{~km}$ running parallel to the coastline, is between 300 and $700 \mathrm{~m}$ in width and currently covers an area of 534.7 ha (GallegoFernández et al., 2006). The spit actively grows eastward at a mean annual rate of around $42 \mathrm{~m}$ over the last 50 years, adding about 1.5 ha of new surface area to the system every year (Muñoz Vallés, unpub. data). The climate is Mediterranean, with an influence from the Atlantic Ocean. Mean annual temperature is $18.2^{\circ} \mathrm{C}$ and mean annual rainfall is $583 \mathrm{~mm}$, with a pronounced drought period from May to September (29 yr. record, 1974-2003; Gibraleón Meteorological Station, Huelva). The spit supports different vegetation communities, largely dependent on geomorphology and sedimentary traits. They range from high beach and active dune communities to interior semi-stabilized and stabilized dunes, interdune wet depressions or 'slacks', salt marshes and tidal swales (Gallego-Fernández et al., 2006). At the beginning of the twentieth

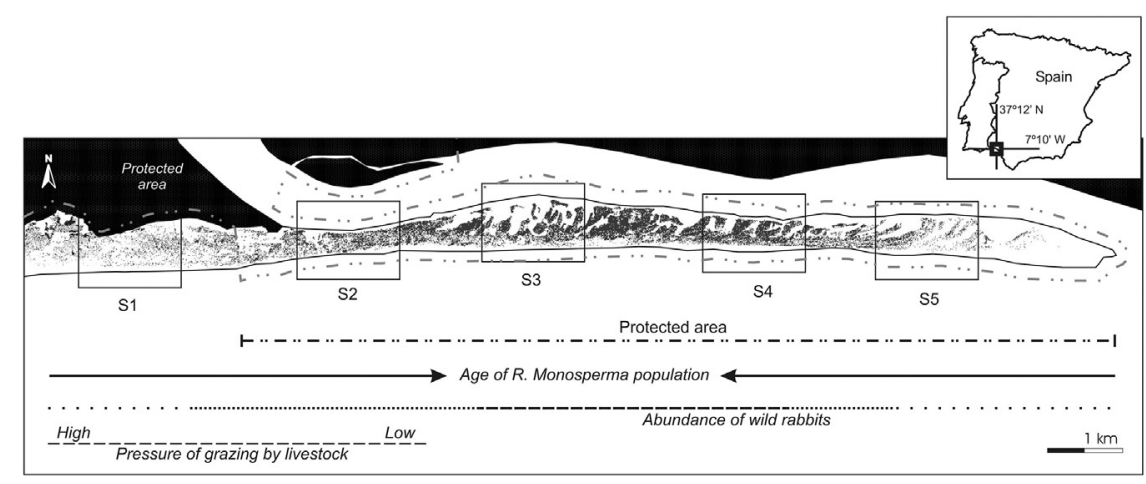

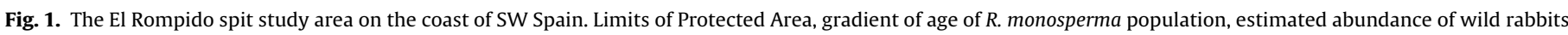

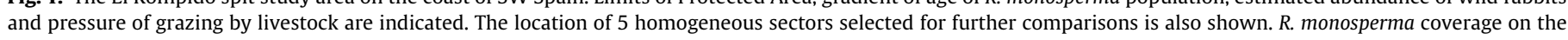
spit in 2001 is represented by black shading. 
century, highly mobile sands with scarce vegetation, dominated by the psammophilous Ammophila arenaria, existed in the area (San Miguel de la Cámara, 1913). In the forties decade, a small $R$. monosperma population located in the central sector of the spit is detectable, and it is presumable that it was planted there in the 1920-30s decades (Gallego-Fernández et al., 2006). At present, the species is widely distributed in almost all the inland dunes.

Most of the spit surface (73\%) has been included in the protected natural area 'Paraje Natural Marismas del Río Piedras y Flecha del Rompido' since 1989 (Fig. 1), and integrated into the European NATURA 2000 network (ES6150006). Nine habitat types, included in Annex I of the European Habitat Directive (Anonymous, 1992) are represented on the spit. This includes semi-stabilized dune habitats (European Communities protected habitats 2130 and 2250) where $R$. monosperma grows. In addition, eleven endangered dune species and subspecies (two of them protected under law) growing on these dune habitats have been recorded in the area (Muñoz Vallés et al., 2009). The spit is subject to low tourist pressure. Grazing by domestic livestock is prohibited within the protected area; nevertheless, low grazing levels still occur within a reduced zone close to the limits of the protected area. Benefitting from the protection policies and low accessibility of the area, an important population of wild rabbits exists in the spit: warrens are estimated to number $444 \pm 161$ (mean \pm S.E.), and are mainly concentrated in the central and central-eastern sectors (Dellafiore et al., 2008) - Fig. 1.

\section{Study species}

Retama monosperma is a mid-successional, N-fixing woody species found in coastal sandy areas, endemic to SW Spain and NW Morocco. Nevertheless, it successfully establishes in other areas under Mediterranean climate around the world (Muñoz Vallés et al., in press). Adult plants attain heights of 3-4.5 m, canopy diameters of up to $10 \mathrm{~m}$ and individual mean coverage of up to $70 \mathrm{~m}^{2}$. Through monitoring individuals by means of historical aerial photography (Muñoz Vallés et al., 2005), it has been estimated that a lifespan of 55-80 years is possible. Clonal growth has not been documented in this species, however, it can produce from $\sim 335$ to $\sim 2800$ fruits per $\mathrm{m}^{2}$ of canopy in the study area, from late May to September. The fruits lack evident dispersal adaptations, and merely fall to the ground where they remain available for dispersers until the next fruiting season (Muñoz Vallés et al., in press). The rapid expansion of the species has been mainly enhanced by the dispersing activities of the wild rabbit (Oryctolagus cuniculus), as well as an improvement in seed germination rates which occurs after the passage of seeds through the rabbit gut (from 13\% to 24\%; Dellafiore et al., 2006, 2010). The species is at present widely distributed in the study area, and is the dominant species in the semi-stabilized dunes, which represent the main habitat on the spit (57\% of the total spit surface; Gallego-Fernández et al., 2006).

\section{Mapping $R$. monosperma coverage}

This study was based upon a temporal sequence of aerial orthophotographs, corresponding to the dates 1956 (B/W, scale 1:33,000), 1977 (B/W, scale 1:18,000), 1989 (colour, scale 1:5000) and 2001 (colour, scale 1:5000). Photographs were scanned at high resolution of $1200 \mathrm{dpi}$, and the central zone of each one was selected in order to avoid edge distortion. They were further geo-rectified using Ground Control Points taken in the field by GPS. Using these, a digital orthophoto mosaic was created for each date and added to a GIS (ArcView 3.2). An additional aerial photograph from 1946 (B/W, scale $1: 45,000)$ was examined. It was not added to the GIS due to low image quality but it was used to delimit the original population of the species in the central sector of the spit.
Individual or groups cover of $R$. monosperma canopies was digitalized into the GIS at an approximate scale of 1:500. It was first mapped on the basis of the most recent date mosaic (2001), with the highest resolution and image quality, and subsequently on the orthophoto mosaics from the dates 1989, 1977 and 1956. The work on each date and map was successively supported in the previously built maps. Due to the availability of photographs, analysis of $90 \%$ of the current total surface of the spit was possible. This excluded a scarce area of 53.47 ha located at the western extreme. Adult individuals of $R$. monosperma were easily recognizable in the photographs due to their texture and tone, their characteristic circular or ellipsoidal shape and their size, significantly larger than adults of the other woody species present, such as Artemisia campestris subsp. crithmifolia, Crucianella maritima Helichrysum italicum subsp. picardii and Thymus carnosus, even from a young age.

\section{Analysis of total coverage and temporal change}

Total analyzed surface, semi-stabilized dune surface (suitable for the establishment of $R$. monosperma; this excludes the beach, embryo dunes and salt marshes), total coverage of the species and percentage of coverage per semi-stabilized dune surface were obtained from the GIS for every studied date. Rate of increase in coverage was subsequently calculated as the regression of the square root of the area covered by the species as a function of time, in accordance with previous models in biological invasion theory (Buell et al., 1995; Skellam, 1951). In addition, the main directions of the populations lateral spread were identified and maximum rates of lateral spread were subsequently calculated as the differences in the population' limits between dates. Spread towards the coastline was estimated only in the $3 \mathrm{~km}$ long central frame of the spit, corresponding to the original population nucleus.

\section{Analysis of spatio-temporal patterns of expansion}

All digital maps of dune surface and $R$. monosperma coverage were divided within the GIS into contiguous $50 \mathrm{~m} \times 50 \mathrm{~m}$ cells using a grid (Brown and Carter, 1998; Middleton et al., 2008). Both dune surface and coverage of $R$. monosperma per dune surface (\%) within each cell were calculated. Due to the heterogeneity of the area, e.g. dune and salt marshes, only those cells in which $>75 \%$ of the surface was dune surface were considered valid cells, and were used in the analyses. This appropriate cell size for change detection was determined after testing it in comparison with another two sizes of cells, $100 \mathrm{~m} \times 100 \mathrm{~m}$ and $25 \mathrm{~m} \times 25 \mathrm{~m}$. The amount of $100 \mathrm{~m} \times 100 \mathrm{~m}$ cells was limited by the heterogeneity of the area, and covered a smaller surface than the $50 \mathrm{~m} \times 50 \mathrm{~m}$ ones did. On the other hand, $25 \mathrm{~m} \times 25 \mathrm{~m}$ cells were too small in size and rapidly reached high percentages of $R$. monosperma coverage. For these reasons, analyses were finally carried out using $50 \mathrm{~m} \times 50 \mathrm{~m}$ cells only.

Cells were classified into five categories according to the coverage of $R$. monosperma per dune surface, as follows: C0: cov. $=0 \%$; C1: $0 \%<\operatorname{cov}$. $\leq 25 \%$; C2: $25 \%<\operatorname{cov} . \leq 50 \%$; C3: $50 \%<\operatorname{cov} . \leq 75 \%$; C4: $75 \%<\operatorname{cov} . \leq 100 \%$. The total number of valid cells per category and date was calculated, and maps of the distribution of cell categories on each date were produced.

\section{Analysis of spatio-temporal change in relation to grazing by domestic livestock and wild rabbit abundance}

Five homogeneous sectors of $1 \mathrm{~km}$ in length each were selected throughout the study area, according to livestock grazing intensity and abundance of wild rabbit. Characteristics of these sectors are indicated in Table 1, and their location is shown in Fig. 1. 
Table 1

Characteristics of sectors (S1-S5) selected for analysis of spatio-temporal change in relation to land use and conservation level.

\begin{tabular}{|c|c|c|c|c|c|}
\hline & $\mathrm{S} 1$ & $\mathrm{~S} 2$ & S3 & S4 & S5 \\
\hline Included in the protected area & No & Yes & Yes & Yes & Yes \\
\hline Intensity of livestock grazinga & High & Low & None & None & None \\
\hline Abundance of wild rabbit ${ }^{\mathrm{b}}$ & Very $\operatorname{low}(0.0)$ & $\operatorname{Low}(1.3)$ & $\operatorname{High}(2.1)$ & The highest(3.0) & Very $\operatorname{low}(0.5)$ \\
\hline Distance from the oldest population nucleous $(\mathrm{km})^{\mathrm{c}}$ & 5.3 & 2.4 & 0 & 2.9 & 5.2 \\
\hline
\end{tabular}

a According to Zunzunegui et al. (2012).

b Mean number of warrens per ha, according to Dellafiore et al. (2008).

c Measured from the centre of the sectors.

Table 2

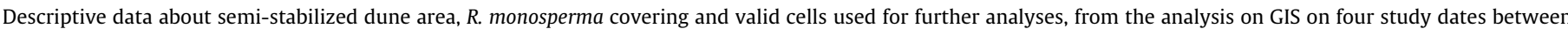
1956 and 2001.

\begin{tabular}{|c|c|c|c|c|}
\hline & 1956 & 1977 & 1989 & 2001 \\
\hline Semi-stabilized dune surface (ha) & 271.53 & 288.94 & 295.51 & 296.84 \\
\hline R. monosperma total coverage (ha) & 15.03 & 44.24 & 75.10 & 116.19 \\
\hline R. monosperma coverage per semi-stabilized dune surface (\%) & 5.53 & 15.31 & 25.41 & 39.14 \\
\hline Number of valid cells $(50 \mathrm{~m} \times 50 \mathrm{~m}$ ) & 823 & 877 & 882 & 884 \\
\hline Semi-stabilized dune surface included in the valid cells (\%) & 68.95 & 71.80 & 71.40 & 71.22 \\
\hline R. monosperma coverage included in the valid cells (\%) & 66.99 & 67.19 & 69.01 & 76.99 \\
\hline
\end{tabular}

Livestock grazing intensity was estimated as mean number of droppings per $\mathrm{m}^{2}$ and mean number of fruits per $\mathrm{m}^{2}$ found below $R$. monosperma canopies, according to Zunzunegui et al. (2012). High intensity corresponded to approximately 16 droppings and less than 5 fruits per $\mathrm{m}^{2}$; low intensity corresponded to approximately 6 droppings and 167 fruits per $\mathrm{m}^{2}$; non-intensity corresponded to 0 droppings and approximately 1158 fruits per $\mathrm{m}^{2}$. Abundance of wild rabbits was estimated as warren density, according to Dellafiore et al. (2008) (Table 1).

For each sector, $R$. monosperma coverage (\% of suitable surface) per useful cell and date was calculated. Mean coverage per cell was compared in the five sectors for each date using one-way ANOVA and the post hoc Tukey test. The rate of increase in coverage was calculated within each sector, over the course of the 45 years studied, as the regression of the square root of the area covered by the species as a function of time (Buell et al., 1995; Skellam, 1951). Data were transformed (arcsine $x$ ) prior to analysis in order to comply with the assumption of homogeneity. For statistical analysis, the statistical software package STATISTICA 6.0 was used.

\section{Results}

\section{Total coverage of $R$. monosperma and temporal change}

Due to growth dynamics of the spit, both the area of the spit in total as well as the area of dunes increased over time (Table 2, Fig. 2). The total area covered by $R$. monosperma substantially increased during the 45 years analyzed; from 15.0 ha occupied in 1956 (5.5\% of dune surface) to 116.2 ha (39.1\% of dune surface) in 2001 . Assuming a linear increase, there was an annual mean increase in the area covered by the species of almost $15 \%$. The mean annual increase in coverage was higher between 1956 and 1977 (9.3\%), but coverage increase in relation to population size was lower between 1977 and 1989 (5.8\%), and between 1989 and 2001 (4.6\%): Table 3. The annual rate of increase in total shrub coverage was found to fit an exponential curve (Fig. 3 ).

Retama monosperma reached the western limit of the digital maps during the first period (1956-1977), and reached the western end of the spit in 1989. Westward lateral spread was the most rapid during the first studied period, advancing more than $120 \mathrm{~m} \mathrm{yr}^{-1}$

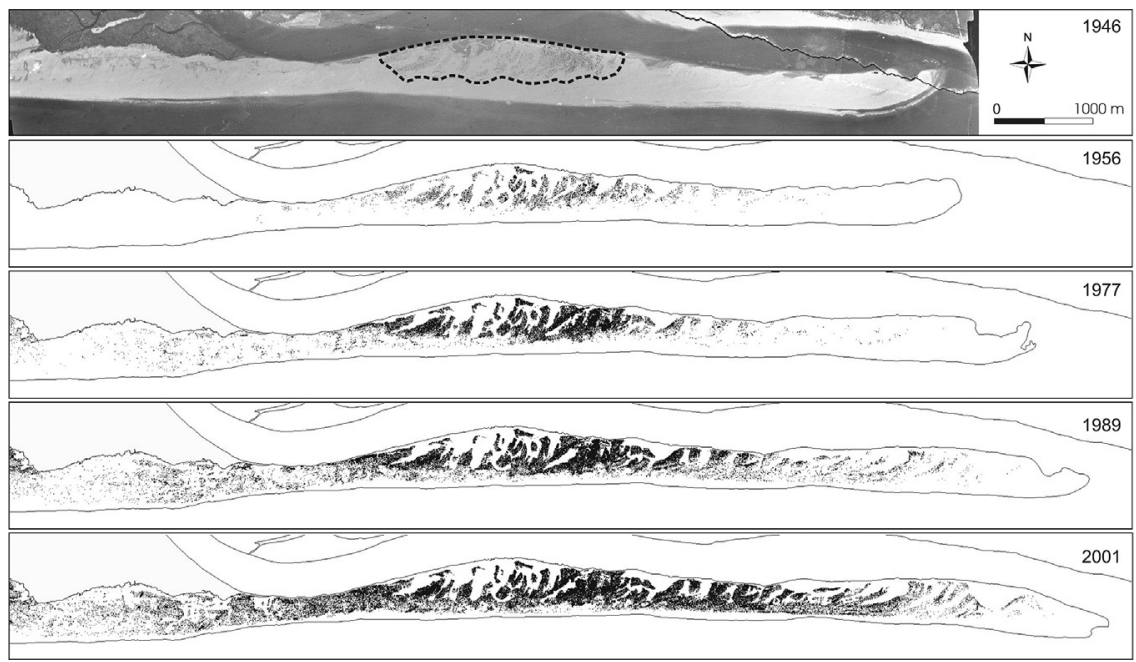

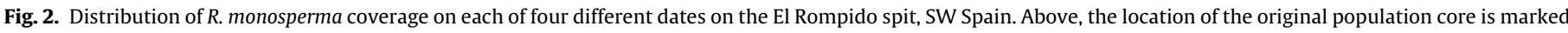
by discontinuous line over an aerial photograph from 1946. 
Table 3

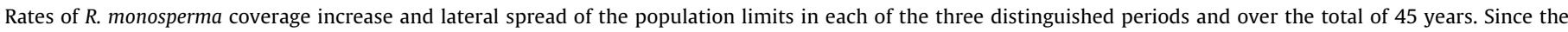

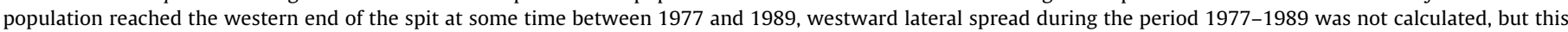
advance was certainly inexistent between 1989 and 2001 .

\begin{tabular}{|c|c|c|c|c|}
\hline & 1956-1977 & 1977-1989 & 1989-2001 & 1956-2001 \\
\hline Total increase of $R$. monosperma coverage (\%) & 194.45 & 69.74 & 54.71 & 673.23 \\
\hline Annual rate of increase in $R$. monosperma coverage (\%) & 9.26 & 5.81 & 4.56 & 14.96 \\
\hline Annual rate of westward lateral spread $\left(\mathrm{m} \mathrm{yr}^{-1}\right)$ & 55.76 & 77.17 & 17.00 & 51.13 \\
\hline Annual rate of eastward lateral spread $\left(\mathrm{m} \mathrm{yr}^{-1}\right)$ & $>120.00$ & - & 0.00 & 79.78 \\
\hline Annual rate of lateral spread towards the coastline $\left(\mathrm{m} \mathrm{yr}^{-1}\right)$ & 1.57 & -1.00 & 1.50 & 0.87 \\
\hline
\end{tabular}

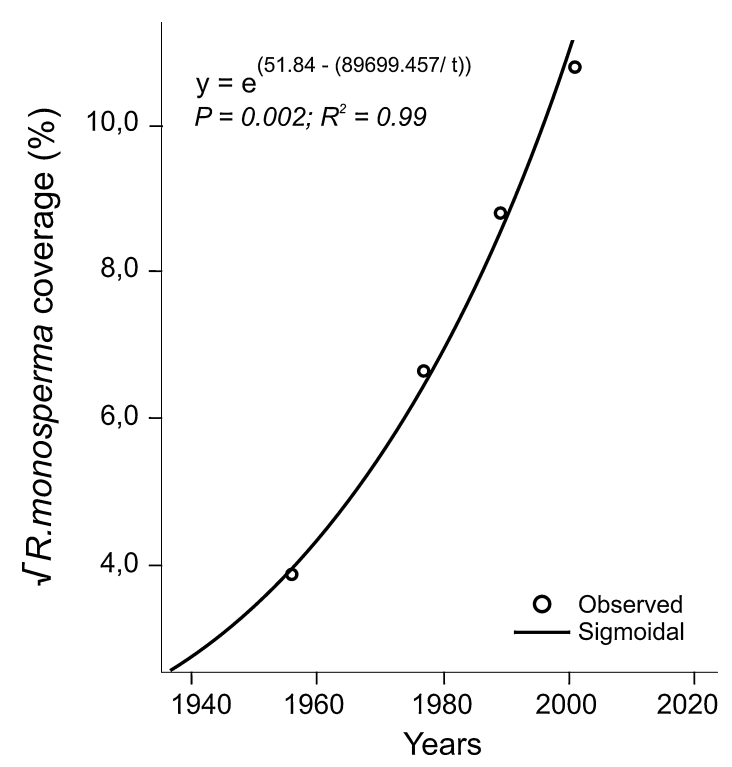

Fig. 3. Increase in R. monosperma coverage on the El Rompido spit, SW Spain, as function of time.

(Table 3). In this case, we were not able to calculate the westwards advance of the population during the period 1977-1989, but we can say that this advance was null between 1989 and 2001 (Table 3 ). The eastward advance was slower in comparison with the westwards advance. A maximum speed of $77.2 \mathrm{~m} \mathrm{yr}^{-1}$ was achieved between 1977 and 1989, and decreased afterwards (Table 3). By 1977, the population had reached an area very close to the eastern extreme of the spit. Nevertheless, the eastern end of the spit had still not been reached by 2001 (Fig. 2).

Lateral spread towards the coastline was between one and two orders of magnitude slower than spread along the length of the spit, at around $0.9 \mathrm{~m} \mathrm{yr}^{-1}$ between 1956 and 2001, and in fact showed a retreat between 1977 and 1989 (Table 3).

\section{Patterns of R. monosperma expansion}

The spit growth dynamics produced an increase in the number of valid cells from 823 to 884 over the studied period. Valid cells

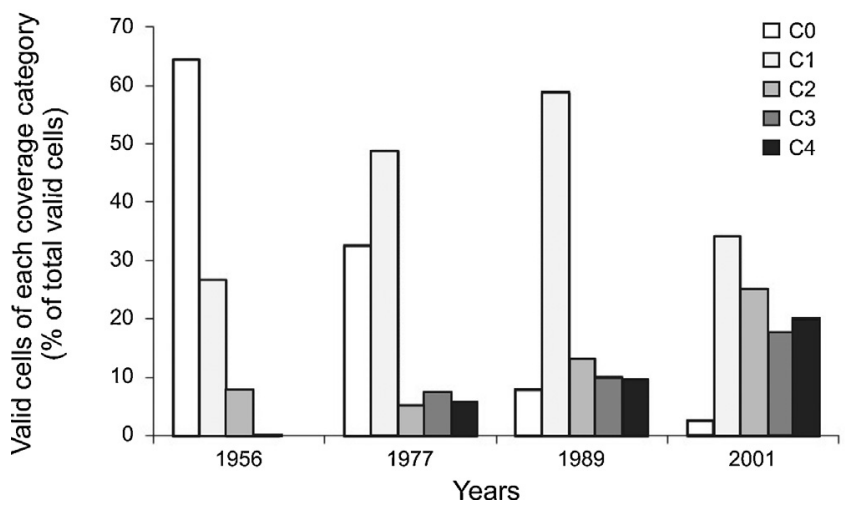

Fig. 5. Relative abundance of valid $50 \mathrm{~m} \times 50 \mathrm{~m}$ cells belonging to each of five coverage categories, as percentage of the total number of valid cells, on each of four analyzed dates.

covered between $69 \%$ and $72 \%$ of the semi-stabilized dune surface and between $67 \%$ and 77\% of the digitalized coverage of $R$. monosperma.

Categorized values of $R$. monosperma coverage were in 2001 higher at the inner, older colonized cells (coverage categories $C 3$ and (4), which were located in the central area of the spit, and lower ( $\mathrm{C} 0$ and $\mathrm{C} 1$ ) in the more recently colonized cells, which were located more to the exterior parts of the spit (Fig. 4). The percentage of empty cells (C0) was higher at the first date analyzed, 1956, but rapidly decreased over time as the population expanded (Fig. 5).

From 1956 to 1977, the population preferentially expanded eastward, and generally maintained a low coverage (below 25\%) outside the central nucleus area. At every date, apart from 1956, the $\mathrm{C} 1$ cells, associated with colonization events, were found to be the most abundant coverage category. The percentage of $\mathrm{C} 1$ cells increased until 1989, when C0 were below $8 \%$, and decreased thereafter. This indicates a change from a predominantly colonization of new cells to a pattern in the final period when the population became more dense. Cells from categories C2, C3 and C4 were generally less abundant than $\mathrm{C} 0$ or $\mathrm{C} 1$, and followed a general increasing trend over time (Fig. 5). The central nucleus area showed moderate or null increases in coverage from 1977 to 2001, while coverage losses were registered in somewhat more than $1 \%$ of cells

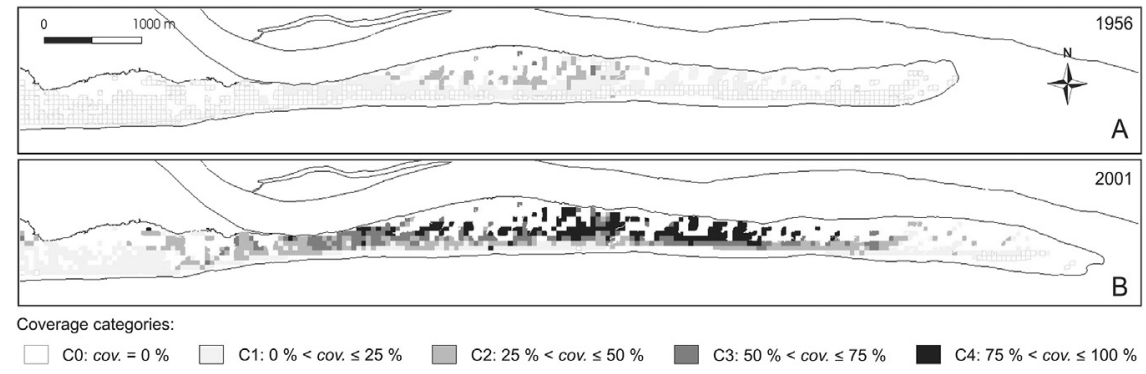

Fig. 4. Distribution of categories of $R$. monosperma coverage (C0-C4) in $50 \mathrm{~m} \times 50 \mathrm{~m}$ cells in 1956 (A) and 2001 (B). 


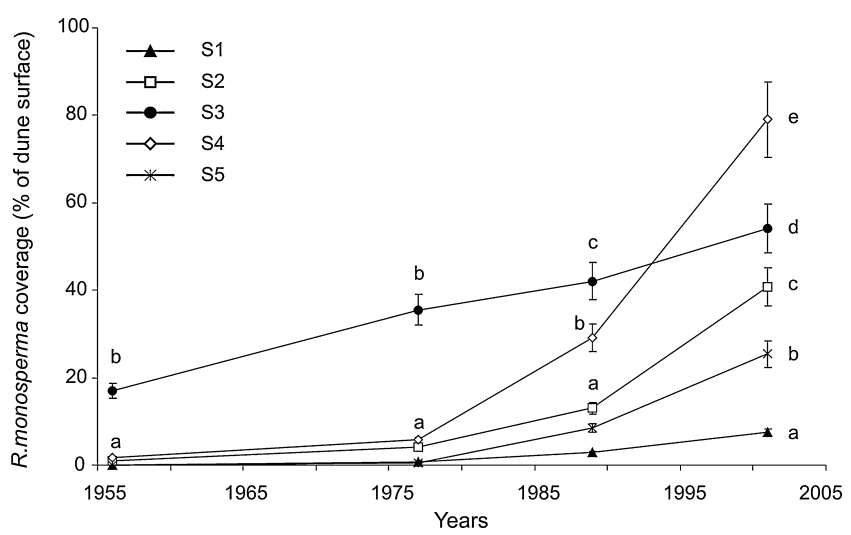

Fig. 6. Increases in R. monosperma coverage in 5 selected sectors of the El Rompido spit, on each of four analyzed dates. S1: outside the protected area, high intensity of livestock grazing, very low rabbit abundance; S2: protected, low intensity of livestock grazing, low rabbit abundance; S3: protected, no grazing by livestock, high rabbit abundance; S4: protected, no grazing by livestock, the highest abundance of rabbits; S5: protected, no grazing by livestock, very low rabbit abundance. Asterisks indicate significant differences found by ANOVA; different letters indicate significant differences.

from 1977 to 1989 and $1.8 \%$ from 1989 to 2001 . Over time, although $R$. monosperma colonized westward more quickly than eastward, the occurrences became denser towards the east. This pattern can be related with the differential effect of grazing by domestic livestock and wild rabbits (Fig. 4).

\section{Patterns of $R$. monosperma expansion in relation to grazing by domestic livestock and wild rabbit abundance}

Grid cells corresponding to the $\mathrm{C} 1$ coverage category, associated with colonization events, increased until 1977 in sectors S2 and S4, and until 1989 in S5, and decreased afterwards. The maximum number of C1 cells in S3 was reached in 1956, decreasing afterwards, while in S1 the maximum was reached in 2001 (data not presented). This indicates a change in dynamics, mainly from colonization of new cells (majority of $\mathrm{C} 1$ ) to population densification (C1 decrease), which varied between sectors studied.

ANOVA revealed significantly higher mean values of $R$. monosperma coverage per cell in S3, the population core, during 1959 and 1977 (1956: $F=65.10 ; P<0.001 ; 1977: F=71.64$; $P<0.001$ ), while the remaining sectors maintained similar and lower values (Fig. 6). Mean coverage per cell continued to be significantly higher in S3 in 1989, while values in S4 significantly increased in comparison with $\mathrm{S} 1, \mathrm{~S} 2$ and $\mathrm{S} 5(F=59.73 ; P<0.001)$. In 2001 , mean coverage per cell showed significantly different values in every sector $(F=144.34 ; P<0.001)$. In this year, the highest coverage values were obtained in $\mathrm{S4}$, exceeding those of the population core (S3), while progressively lower values were obtained in S3, S2, S5 and S1 (Fig. 6). The annual rate of increase in coverage fitted an exponential curve in sectors $S 1\left(P=0.002 ; R^{2}=0.99\right)$, S2 $(P=0.004$; $\left.R^{2}=0.99\right)$, S4 $\left(P=0.016 ; R^{2}=0.97\right)$ and $\mathrm{S} 5\left(P=0.023 ; R^{2}=0.96\right)$, but it fitted a lineal curve in sector S3 $\left(P=0.007 ; R^{2}=0.99\right)$.

\section{Discussion}

Our study shows that Retama monosperma has rapidly expanded in the open, semi-stabilized dunes over the 45 year period covered by the data, from an original central nucleus estimated to have been founded in the 1920s to 1930s (Gallego-Fernández et al., 2006). Speed of lateral spread exceeded $108 \mathrm{~m} \mathrm{yr}^{-1}$, and still the population is actively colonizing dune surfaces that newly become available. A substantial increase in coverage of $673 \%$ occurred during those 45 years, and at present a predominant dynamic of population densification can be registered. The stand have the potential for further encroachment. This expansion has in turn contributed to the stabilization of much of the dune system, inducing substantial changes in the dune flora and vegetation structure (Muñoz Vallés et al., 2011; Zunzunegui et al., 2012).

According to Alpert et al. (2000), in ecosystems characterized by stressful environmental conditions, certain regionally native species may display more acutely invasive expansion as compared to alien species, as a result of being better adapted to those conditions. The annual growth rate in coverage of $R$. monosperma (15\%) was significantly higher than the $2.9 \%$ found for the alien Acacia saligna in an analysis of data over 34 years by Kutiel et al. (2004b) in coastal dunes of Israel. It was similar to values registered by Kollmann et al. (2009) for the alien Rosa rugosa (16.4\%; 18 years analyzed) in coastal dunes of Denmark. The annual rate of lateral expansion of the $R$. monosperma population $\left(65.5 \mathrm{~m} \mathrm{yr}^{-1}\right)$ was also significantly higher than the lateral expansion rate of other woody species in coastal dunes of England reported by Fuller and Boorman (1977; $5 \mathrm{~m} \mathrm{yr}^{-1}$ for the shrubs Rhododendron ponticum and Hippophäe rhamnoides). The observed trend of expansion of $R$. monosperma in coastal dunes of southern Spain is therefore comparable to the invasive-type expansion exhibited by allochthonous invasive species (see also Buell et al., 1995). The linear trend of increase in population density shown in the central sector of the spit could be related to the simultaneous growth of a majority of individuals of the same age, deliberately introduced to fix dunes near to the tunny fishery that was active in this sector during the first half of 20th century. This fact must be taken into account when interpreting the results, as the historical mass plantation of $R$. monosperma that occurred there, means that the natural slow introduction and establishment phases of invasion dynamics did not occur in this case. Judging about the invasive potential of $R$. monosperma it must be taken into account generally, that this species is also used as an ornamental plant, a fact which facilitates its introduction into new areas (Talavera, 1999). Resulting from such introductions, R. monosperma is presently considered to be a non-native invasive plant of coastal shrublands, grasslands, and the chaparral in California, USA (CalIPC, 2006; Randall, 1997; Rejmanek and Randall, 1994), and an invasive, noxious weed on the coasts of SW Australia (Randall, 2007).

The recorded annual growth rate of $R$. monosperma coverage on the investigated spit was found to be 9.8 times that which Kutiel et al. (2004a) found for the total vegetation coverage ( $1.8 \%$; $34 \mathrm{yr}$.) in plant-colonized coastal dunes under Mediterranean climate of southern Israel. In that study, the expansion of vegetation was found to be related to the dune stabilization process and to a decrease in the abundance of sand-dwelling organisms. The expansion of $R$. monosperma, and in consequence the progressive stabilization of dunes, in the El Rompido spit and other dune systems in SW Spain, have negative consequences for the conservation of semi-stabilized dunes (European Communities protected habitat 2130 and 2250; Anonymous, 1992). In addition to the rapid expansion, the species could induce significant changes in the local environment that may facilitate the recruitment of species less tolerant to environmental stress (mainly nitrophilous, ruderal and/or weed species, such as Anagallis arvensis, Erigeron sumatrensis, Paronychia argentea, Solanum alatum and Urtica membranacea, among others). Further, it may negatively affect the dune flora beneath the canopy, increasingly with higher $R$. monosperma age and coverage (Muñoz Vallés et al., 2011; Zunzunegui et al., 2012). This significant alters the vegetation abundance, composition and structure, with negative effects upon other dune plant species the vitality of which will suffer from the decline of open, semistabilized dunes (Muñoz Vallés et al., 2009, 2011). In this way, $R$. monosperma behaves as a native-invasive species, and shows a 
high potential for inducing significant functional changes within the dune ecosystem.

In agreement with Valéry et al. (2009), this study supports the idea that the expansion of native-invasive species may have negative effects on ecosystem diversity and stability. In addition, it may have great relevance for the conservation of properties and processes within the ecosystems under $R$. monosperma invasion, likewise as it would be the case of an invasive spread of alien species.

Excessive coverage of $R$. monosperma should therefore be controlled and managed in some locations of SW Spain and S Portugal, in order to preserve the existing plant communities and the persistence and functioning of semi-stabilized dune habitats. In this regard, it has been observed that seawater inundation by high tides causes obvious physiological damage to this native-invasive species, and sand burial and saltwater intrusion appear to limit its establishment (Muñoz Vallés et al., in press). It has been also observed that $R$. monosperma seedlings and young stands develop successfully in open areas, but recruitment under adult canopies of the species is very limited. Rey Benayas et al. (2002) found significant competition between weeds and $R$. sphaerocarpa seedlings when growing together, but shading (e.g. provided by Retama adults) improved performance of the seedlings. These latter seemed to be in a competition for water resources with weeds. This same interaction could occur between Retama adults and seedlings, so adults could control the population recruitment under its canopies through competition - but this should not solve the expansion problem. In this regard, further studies are required in order to assess the factors that limit seedling establishment and survival.

Previous studies have identified wild rabbits as important dispersers of $R$. monosperma in coastal dunes (Dellafiore et al., 2006, 2010). It is estimated that each rabbit could disperse between 2484 and 4041 seeds $\mathrm{yr}^{-1}$, at both short and long distances (up to $335 \mathrm{~m}$ from the nearest mature plant of $R$. monosperma), contributing to the development of the species seed bank. In addition, passage through the rabbit gut improves seed germination rates, from $13 \%$ to $24 \%$, (Dellafiore et al., 2006). These processes certainly have facilitated - and continue doing so - the rapid lateral expansion of the $R$. monosperma population over the continuous dune surface. They contribute also to overcome obstacles in the dune surface represented by salt marshes and tidal swales (GallegoFernández et al., 2006). As in previous studies found, the interaction between wild rabbits and $R$. monosperma works as a feed-back system, where the rabbit acts as seed disperser over short and long distances and improves seed germination rates (Dellafiore et al., 2006), while $R$. monosperma in turn provides rabbits with refuge space and food (Dellafiore et al., 2008). Our results show a long-term net increase of the extent and coverage of the shrub population in areas where rabbits are distributed, without the concurrence of another type of disturbance, a situation which leads to the stabilization of the dune system. This clearly contrasts with previous studies of grazing in European coastal dunes, where rabbits play an important role in maintaining low levels of vegetation coverage and increasing sand dune mobility (Burggraafvan Nierop and van der Meijden, 1984; Hodgkin, 1984; Ranwell, 1960).

In contrast, sectors subjected to grazing by livestock showed significantly lower increases in $R$. monosperma coverage over time, which was even lower in the area subjected to higher pressure (S1). This led to maintenance of an open type of plant community for a longer period of time. This retarding effect on expansion and densification of the $R$. monosperma population probably results from high consumption rates of the Retama fruits by goats and sheep (Zunzunegui et al., 2012), as well as by a poor capacity of these animals for dispersal. Castro et al. (2005) found that passage of
Retama sphaerocarpa seeds through the gut of livestock did not significantly increase germination rates, except where the seed had been damaged during mastication. However, we found that passage through goat digestive systems (where the seed remained inside the gut from 1 to 5 days), increased subsequent germination rates from $5 \%$ (in non-consumed seeds) to $48 \%$ (Muñoz Vallés, unpublished data). Over a five days observation period we found a final $32 \%$ seed recovery from excrements of the experimentally studied goats. This, together with the final germination rate data (weighted to mean daily recovery), resulted in a final effective germination percentage of $16 \%$, which was similar to the rates in control seeds (13\%) reported by Dellafiore et al. (2006). In this comparison, it is important to take into account the loss of seeds due to consumption and subsequent defecation by goats outside the dune system. This does not occur to the same extent in the case of seed consumption by rabbits, as they are resident within the dune system. In addition, predation on seedlings of $R$. monosperma by domestic livestock has been not quantified. Our results concur with those of other studies where livestock grazing contributes to the maintenance of open-type plant communities as well as to the mobility of sands, due to the decrease in vegetation coverage (Kooijman and Van der Meulen, 1996; Levin and Ben-Dor, 2004; Manzano and Návar, 2000; Zhao et al., 2005). In this way, the observed coverage increase in sector S2 from 1989 to 2001 could be related to the reduction in intensity of pasture activities that followed the declaration of the site as a protected area (1989). According to the results reported by other authors, such effects of livestock activity on dune vegetation can change, depending on factors such as soil characteristics (Kohyani et al., 2008; Van Dijk, 1992; Zuo et al., 2008), intensity of grazing (Carter, 1988), or also the monitoring scale (Kohyani et al., 2008). In some cases, decreasing competitive interactions caused by high grazing pressure have resulted in the loss of grasslands and the further development of shrub formations (Isermann et al., 2007; Roth et al., 2009). However, other negative effects of livestock pasture activities there, like trampling, soil compaction and eutrophication or dispersion of adventitious species from outside the system have not yet been quantified. Low to medium coverage of $R$. monosperma would be positive for the survival of the endangered reptile Chamaeleo chamaeleon, that is present on the study area, but intensive grazing and trampling by domestic livestock would be very harmful for the reproduction of this species, since they lay their eggs on the soil.

Implementation of grazing by livestock may appear to be a suitable management tool for the control of excessive coverage of $R$. monosperma in these coastal dunes, and it has been advocated, indeed, by Plassmann et al. (2010). However, the potential consequences of adopting such a management strategy in a fragile dune ecosystem need to be understood more fully (Raffaele et al., 2007). Zunzunegui et al. (2012) in a study at the El Rompido spit investigating the effects of different herbivory intensity and density of $R$. monosperma on an endangered shrub species, Thymus carnosus, discourage the management with livestock. They anticipate the future extinction of $T$. carnosus in the dunes because it suffers from the competition with $R$. monosperma, although the speed of this process would be conditioned by the livestock pressure intensity. This latter study proposes, in terms of $T$. carnosus population conservation, a clear-cutting management of $R$. monosperma plants, reducing by this way their number in order to maintain open dunes spaces.

\section{Acknowledgements}

We thank the Spanish Ministry of Environment (Coastal Delegation) for funding, and the staff of the Marismas del Piedras y Flecha Litoral de El Rompido protected area for their help and 
support. Thanks also to K. MacMillan for translation and revision of the English version of the manuscript.

\section{References}

Alpert, P., Bone, E., Holzapfel, C., 2000. Invasiveness, invisibility and the role of environmental stress in the spread of non-native plants. Persp. Plant Ecol. Evol. Syst. 3, 52-66.

Alvarez, M.E., Cushman, J.H., 2002. Community level consequences of a biological invasion: effects of a non-native vine on three plant communities. Ecol. Appl. $12,1434-1444$.

Anonymous, 1992. European Communities Council, Directive 92/43/CEE on the Conservation of Natural Habitats and of Wild Fauna and Flora. European Communities, Brussels.

Ansley, R.J., Wu, X.B., Kramp, B.A., 2001. Observation: long-term increases in mesquite canopy cover in a north Texas savanna. J. Range. Manage. 54, 171-176.

Avis, A.M., 1989. A review of coastal dune stabilization in the Cape Province of South Africa. Landscape Urban Plan. 18, 55-68.

Avis, A.M., 1995. An evaluation of the vegetation developed after artificially stabilizing South African coastal dunes with indigenous species. J. Coastal Conserv. $1,41-50$.

Brown, J.R., Carter, J., 1998. Spatial and temporal patterns of exotic shrub invasion in an Australian tropical grassland. Landscape Ecol. 13, 93-103.

Buell, A.C., Pickart, A.J., Stuart, J.D., 1995. Introduction history and invasion patterns of Ammophila arenaria on the north coast of California. Conserv. Biol. 9, 1587-1593.

Burggraaf-van Nierop, Y.D., van der Meijden, E., 1984. The influence of rabbit scrapes on dune vegetation. Biol. Conserv. 30, 133-146.

Cal-IPC, 2006. California Invasive Plant Inventory. Cal-IPC Publication 200602. California Invasive Plant Council, Berkeley, CA. Available from http://www.cal-ipc.org (accessed April 2011).

Carter, R.W.G., 1988. Coastal Environment. An Introduction to the Physical, Ecological and Cultural Environment. Academic Press, London.

Castro, J., González Miras, E., Robles, A.B., 2005. Effects of ruminal incubation and goats' ingestion on seed germination of two legume shrubs: Adenocarpus decorticans Boiss. and Retama sphaerocarpa (L.) Boiss. Options Méditerranéennes. Series A 67, 111-115.

Conser, C., Connor, E.F., 2009. Assessing the residual effects of Carpobrotus edulis invasion, implications for restoration. Biol. Invasions 11, 349-358.

Dellafiore, C.M., Gallego-Fernández, J.B., Muñoz Vallés, S., 2008. Habitat use for warren building by European rabbits (Oryctolagus cuniculus) in relation to landscape structure in a sand dune system. Acta Oecol. 33, 372-379.

Dellafiore, C.M., Muñoz Vallés, S., Gallego-Fernández, J.B., 2006. Rabbits (Oryctolagus cuniculus) as dispersers of Retama monosperma (L.) Boiss. Seeds in a coastal dune system. Ecoscience 13, 5-10.

Dellafiore, C.M., Gallego-Fernández, J.B., Muñoz Vallés, S., 2010. The rabbit (Oryctolagus cuniculus) as a seed disperser in a coastal dune system. Plant Ecol. 206, 251-261.

El-Bana, M.I., Nijs, I., Kockelbergh, F., 2002. Microenvironmental and vegetational heterogeneity induced by phytogenic nebkhas in an arid coastal ecosystem. Plant Soil 247, 283-293.

Fuller, R.M., Boorman, L.A., 1977. The spread and development of Rhododendron ponticum L. on dunes at Winterton, Norfolk, in comparison with invasion by Hippophäe rhamnoides L. at Saltfleetby, Lincolnshire. Biol. Conserv. 12, 83-94.

Gallego-Fernández, J.B., Muñoz Vallés, S., Dellafiore, C., 2006. Flora and Vegetation on Nueva Umbría Spit (Lepe, Huelva). Lepe Council, Huelva.

Hodgkin, S.E., 1984. Scrub encroachment and its effects on soil fertility on Newborough Warren, Anglesey, Wales. Biol. Conserv. 29, 99-119.

Isermann, M., 2008. Expansion of Rosa rugosa and Hippophaë rhamnoides in coastal grey dunes: effects at different spatial scales. Flora 203, 273-280.

Isermann, M., Diekmann, M., Heemann, S., 2007. Effects of the expansion by Hippophaë rhamnoides on plant species richness in coastal dunes. Appl. Veg. Sci. 10, 33-42.

Jørgensen, R.H., Kollmann, J., 2008. Invasion of coastal dunes by the alien shrub Rosa rugosa is associated with roads, tracks and houses. Flora 204, 289-297.

Kith-y-Tassara, M., 1946. El problema de las dunas del SO de España. Revista Montes 11, 414-419.

Kohyani, P.T., Bossuyt, B., Bonte, D., et al., 2008. Grazing as a management tool in dune grasslands: evidence of soil and scale dependence of the effect of large herbivores on plant diversity. Biol. Conserv. 141, 1687-1694.

Kollmann, J., Jørgensen, R.H., Roelsgaard, J., et al., 2009. Establishment and clonal spread of the alien shrub Rosa rugosa in coastal dunes - a method for reconstructing and predicting invasion patterns. Landscape Urban Plan. 93, 194-200.

Kooijman, A.M., Van der Meulen, F., 1996. Grazing as a control against 'grasencroachment' in dry dune grasslands in the Netherlands. Landscape Urban Plan. 34, 323-333.

Kutiel, P., Cohen, O., Shoshany, M., et al., 2004a. Vegetation establishment on the southern Israeli coastal sand dunes between the years 1965 and 1999. Landscape Urban Plan 67, 141-156.

Kutiel, P., Cohen, O., Shoshany, M., 2004b. Invasion rate of the alien species Acacia saligna within coastal sand dune habitats in Israel. Isr. J. Plant Sci. 52, 115-124.

Levin, N., Ben-Dor, E., 2004. Monitoring sand dune stabilization along the coastal dunes of Ashdod-Nizanim, Israel, 1945-1999. J. Arid Environ. 58, 335-355.
Lichter, J., 1998. Primary succession and forest development on coastal Lake Michigan sand dunes. Ecol. Monogr. 68, 487-510.

Manzano, M.G., Návar, J., 2000. Processes of desertification by goats overgrazing in the Tamaulipan thornscrub (matorral) in north-eastern Mexico. J. Arid Environ. $44,1-17$.

Marchante, E., Kjøller, A., Struwe, S., Freitas, H., 2008. Short- and long-term impacts of Acacia longiflora invasion on the belowground processes of a Mediterranean coastal dune ecosystem. Appl. Soil Ecol. 40, 210-217.

Middleton, M., Närhi, P., Sutinen, M.L. et al., 2008. Object based change detection of historical aerial photographs reveals altitudinal forest expansion. GEOBIA 2008 - Internat. Arch. Photogrammetry, Remote Sens. Spatial Inform. Sci. 38 (http://www.isprs.org/proceedings/XXXVIII/4-C1/).

Muñoz Vallés, S., Gallego-Fernández, J.B., and Dellafiore, C., 2005. Spatial and temporal pattern of Retama monosperma spread in the spit of El Rompido (Gulf of Cadiz, SW Spain). Europ. IALE Congr., 'Landscape Ecology in the Mediterranean, inside and outside approaches' (Faro, Portugal), Abstract book p. 101.

Muñoz Vallés, S., Gallego-Fernández, J.B., Dellafiore, C., 2009. Estudio florístico de la Flecha Litoral de El Rompido (Lepe, Huelva). Análisis y catálogo de la flora vascular de los sistemas de duna y marisma. Lagascalia 29, 43-88.

Muñoz Vallés, S., Gallego-Fernández, J.B., Dellafiore, C.M., Cambrollé, J., 2011. Effects on soil, microclimate and vegetation of the native-invasive Retama monosperma (L.) in coastal dunes. Plant Ecol. 212, 169-179.

Muñoz Vallés, S., Gallego Fernández, J.B., Cambrollé, J. The biological flora of coastal dunes and wetlands: Retama monosperma (L.) Boiss. J. Coastal Res. online, do 10.2112/JCOASTRES-D-12-00013.1, in press.

Nielsen, K.E., Degn, H.J., Damgaard, C., Bruus, M., Nygaard, B., 2011. A native species with invasive behaviour in coastal dunes: evidence for progressing decay and homogenization of habitat types. Ambio 40, 819-823.

Panario, D., Piñeiro, G., 1997. Vulnerability of oceanic dune system under wind pattern change scenarios in Uruguay. Clim. Res. 9, 67-72.

Peters, D.P.C., Yao, J., Gosz, J.R., et al., 2006. Woody plant invasion at a semi-arid/arid transition zone: importance of ecosystem type to colonization and patch expansion. J. Veg. Sci. 17, 389-396.

Plassmann, K., Jones, M.L.M., Edwards-Jones, G., 2010. Effects of long-term grazing management on sand dune vegetation of high conservation interest. Appl. Veg. Sci. 13, 100-112.

Pye, K., 1983. Coastal dunes. Prog. Phys. Geogr. 7, 531-557.

Raffaele, E., Kitzberger, T., Veblen, T., 2007. Interactive effects of introduced herbivores and post-flowering die-off of bamboos in Patagonian Nothofagus forests. J. Veg. Sci. 1, 371-378

Randall, J.M., 1997. Weed Alert! New invasive weeds in California. In: Sympos. Proc California Exotic Pest Plant Council, Sacramento/California, pp. 1-6.

Randall, R.P., 2007. The Introduced Flora of Australia and its Weed Status. CRC for Australian Weed Management, Adelaide.

Ranwell, D.S., 1960. Newborough Warren, Anglesey: III. Changes in the vegetation on parts of the dune system after the loss of rabbits by mixomatosis. J. Ecol. 2 385-395.

Ranwell, D.S., 1972. Ecology of Salt Marshes and Sand Dunes. Chapman and Hall, London.

Rejmanek, M., Randall, J.M., 1994. Invasive alien plants in California: 1993 summary and comparison with other areas in North America. Madroño 41 $161-177$.

Rey Benayas, J.M., López-Pintor, A., García, C., de la Cámara, N., Strasser, R., Gómez Sal, A., 2002. Early establishment of planted Retama sphaerocarpa seedlings under different levels of light, water and weed competition. Plant Ecol. 159, 201-209.

Roth, G.A., Whitford, W.G., Steinberger, Y., 2009. Small mammal herbivory: feedbacks that help maintain desertified ecosystems. J. Arid Environ. 73, 62-65.

Sakai, A.K., et al., 2001. The population biology of invasive species. Annu. Rev. Ecol. Syst. 32, 305-332.

San Miguel de la Cámara, M., 1913. Las costas en la provincia de Huelva y sus variaciones en el periodo histórico. Bol. R. Soc. Esp. Hist. Nat. 13, 434-465.

Skellam, J.G., 1951. Random dispersal in theoretical populations. Biometrika 38 196-218.

Talavera, S., 1999. Retama Raf. In: Talavera, S., Acedo, C., Castroviejo, S. (Eds.), Flora Iberica, vol. VII. CSIC, Madrid, pp. 45-119.

Thomas, A.S., 1963. Changes in vegetation since the advent of myxomatosis. J. Ecol. 2, 287-306

Tsoar, H., 2005. Sand dunes mobility and stability in relation to climate. Physica A $357,50-56$

Tsoar, H., Levin, N., Porat, N., Maia, L.P., Herrmann, H.J., Tatumi, S.H., Claudino-Sales, V., 2009. The effect of climate change on the mobility and stability of coastal sand dunes in Ceará State (NE Brazil). Quat. Res. 71, 217-226.

Valdés, B., Girón, V., Sánchez Gullón, E., Carmona, I., 2007. Catálogo florístico de Espacio Natural de Doñana (SO de España). Plantas Vasculares. Lagascalia 27. 73-362.

Valéry, L., Fritz, H., Lefeuvre, F., Simberloff, D., 2009. Ecosystem-level consequences of invasions by native species as a way to investigate relationships between evenness and ecosystem function. Biol. Invasions 11, 609-617.

Van Auken, O.W., 2000. Shrub invasions of North American semiarid grasslands Annu. Rev. Ecol. Syst. 31, 197-215.

Van Dijk, H.W., 1992. Grazing domestic livestock in Dutch coastal dunes: experiments, experiences and perspectives. In: Carter, B., Curtis, T.G.F. Sheehy-Skeffington, M.J. (Eds.), Coastal Dunes: Geomorphology, Ecology and Management for Conservation. Proc. 3rd Europ. Dune Congr, Galway, Ireland, pp. 235-250. 
Vilà, M., Ibáñez, I., 2011. Plant invasions in the landscape. Landscape Ecol. 26, 461-472.

Wiedemann, A.M., Pickart, A., 1996. The Ammophila problem on the Northwest Coast of North America. Landscape Urban Plan. 34, 287-299.

Yizhaq, H., Ashkenazy, Y., Tsoar, H., 2007. Why do active and stabilized dunes coexist under the same climatic conditions? Phys. Rev. Lett. 98, 188001-1-188001-4.

Zhao, H.L., Zhao, X.Y., Zhou, R.L., Zhang, T.-H., Drake, S., 2005. Desertification processes due to heavy grazing in sandy rangeland, Inner Mongolia. J. Arid Environ. 62, 309-319.
Zunzunegui, M., Esquivias, M.P., Oppo, F., Gallego-Fernández,J.B., 2012. Interspecific competition and livestock disturbance control the spatial pattern of two coastal dune shrubs. Plant Soil 354, 299-309.

Zuo, X., Zhao, H., Zhao, X., Zhang, T., Guo, Y., Wang, S., Drake, S., 2008. Spatial pattern and heterogeneity of soil properties in sand dunes under grazing and restoration in Horquin Sandy Land, Northern China. Soil Tillage Res. 99, 202-212. 